\title{
Circulating tumor cells in breast cancer patients
}

\author{
Minireview
}

B. BYSTRICKY ${ }^{1, \star}$, M. MEGO ${ }^{2}$

${ }^{1}$ Oncology Department, Faculty Hospital Trencin, Trencin, Slovakia; ${ }^{2} 2$ nd Department of Medical Oncology, National Cancer Institute and Translational Unit, Faculty of Medicine, Comenius University, Bratislava, Slovakia

${ }^{*}$ Correspondence: brano.bystricky@gmail.com

Received April 21, 2015 / Accepted August 26, 2015

\begin{abstract}
Circulating tumor cells (CTCs) represent a potential non-invasive substitute for real-time tissue biopsy. Moreover, detection of CTCs in breast cancer patients has been reported as a strong prognostic factor. Biomarkers on CTCs have been analysed and correlated to tissue biopsies from breast cancer patients. Discordance in expression of potential biomarkers between primary tumor, metastatic sites and CTCs has been observed. Potential analytical confounding factors include lack of analytical consistency, varying sensitivities and specificities of used assays and differences in analytical ranges among various reported studies. Besides, clonal evolution within primary tumor (and metastatic sites) that leads to intratumor heterogeneity must be accounted for. Nevertheless, several on-going trials are exploring CTCs detection and biomarker profiling in view of personalising cancer treatment based on these real-time results. In this work, we will review CTCs in breast cancer patients and focus on identification of novel prognostic biomarkers.
\end{abstract}

Key words: circulating tumor cells, breast cancer, biomarkers

Breast cancer the most common malignancy diagnosed in women - an estimated 1.67 million new cases were diagnosed world-wide in 2012, with Western Europe having the highest incidence of 96 per 100,000 (Figure 1).

In Slovakia, 2600 new cases were diagnosed in 2012. Breast cancer currently ranks as a second cause of death from cancer (lung cancer being first) in developed countries. [1] There is no known prevention for breast cancer and an estimated life-time (80 years) absolute risk of development of breast cancer is 1 in 8 to 1 in 10 women. Fortunately, during the early decades of life, the odds are lower (1 in 228 for 30-year old woman). [2] Despite advances in screening, diagnosis and treatment, significant portion of patients is diagnosed in advanced stages or develops metastatic disease. Median survival of stage IV disease is about 28 months, depending on type and site of disease. [3] This failure has been associated with different tumor factors and biology, including various subtypes of breast cancer (e.g. luminal, basal), distinct cell populations in a tumor (intratumor heterogeneity) and existence of cancer stem cells that are in part responsible for tumor resistance, dormancy and spread. [4]

\section{Metastatic cascade}

Cancer is characterised by Darwinian evolution. [5] Nextgeneration sequencing (NGS) studies show that clonal evolution occurs within primary tumor and continues in metastatic disease as well. These cell clones can disseminate into distant organs where they can readily develop further metastatic foci or can remain dormant. Tumor dormancy is thought to be responsible for late recurrences, for example in luminal breast cancer type. Different hypotheses have been proposed regarding origin and metastases-forming capability of escaping cells into circulation. However invasion-metastatic cascade is a common cascade that tumor cells must complete to exit primary tumor and establish a new metastatic deposit at a distant site. It involves local invasion through extracellular matrix (ECM), intravasation into circulation, migration through blood stream, arrest and extravasation into distant organs, survival and re-initiation of their proliferative potential. [6]

Millions of tumor cells are shed daily into circulation, however experimental data suggests that only tiny fraction of these 


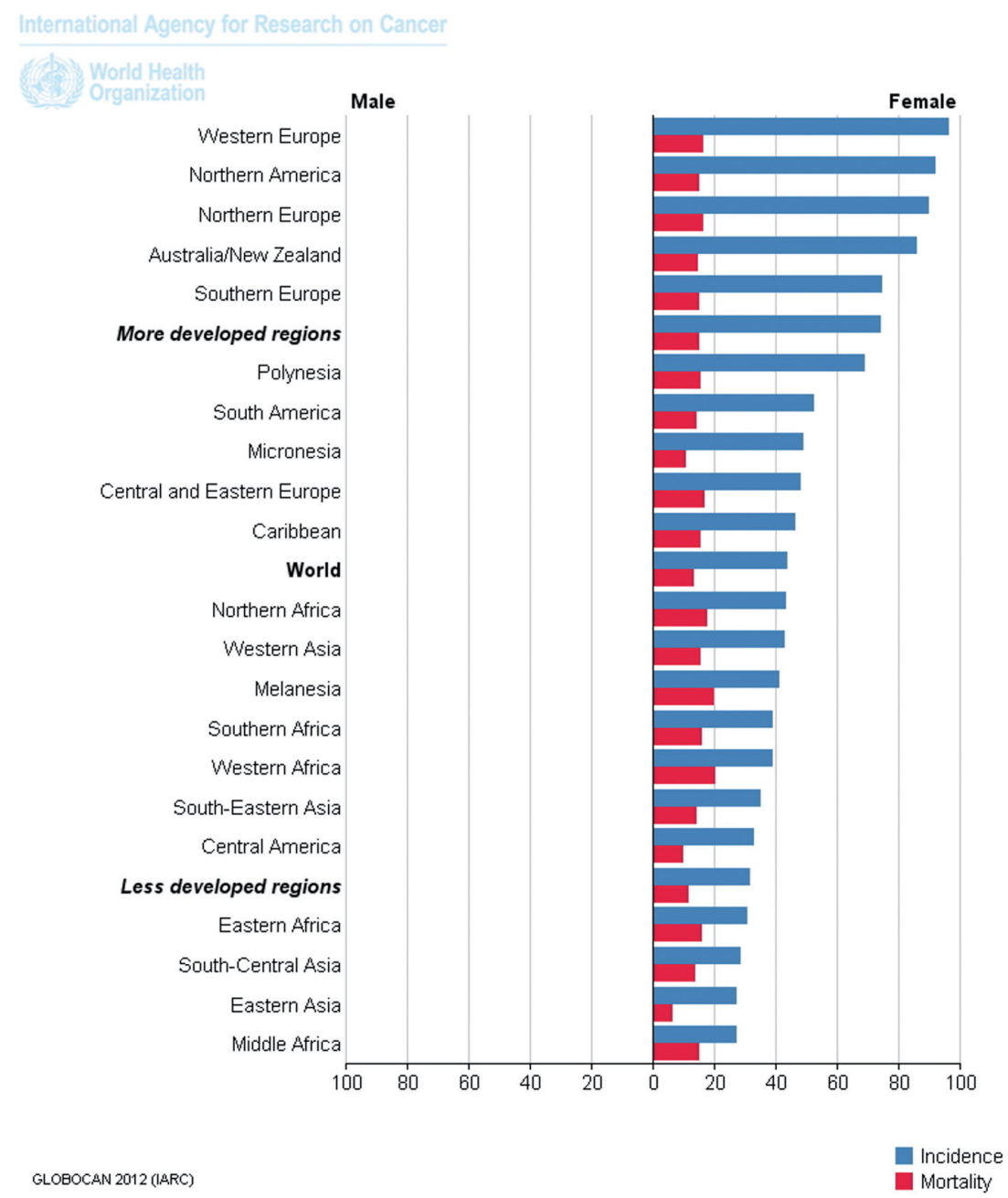

Figure 1. Estimated age-standardised rates (World) per 100,000. From [1]

circulating tumor cells (CTCs) are able to form macroscopic metastases. [7]

Local invasion. Local invasion is first step in the metastatic process. Cancer cells must breach ECM, which requires changes in cell-cell and cell-ECM adhesion molecules. Two different types of individual cell invasion have been recognised: mesenchymal invasion (integrin-dependent, typical of dedifferentiated epithelial cancers) and amoeboid invasion (integrin-independent, typical of lymphoma) with possibility of interconversion between them. [8]

In mesenchymal invasion, down-regulation of E-cadherin with up regulation of $\mathrm{N}$-cadherin is observed. Invasion is further helped by proteolytic degradation of ECM, mediated by matrix metalloproteinases (MMPs) and the urokinase plasminogen activator system (uPA). A significant number of CTCs display amplification of uPA receptor which is responsible for liberation of active plasmin and subsequent degradation of ECM. [9] In mesenchymal-cell migration, cancer cells undergo cell-biological program known as epithelial-mesenchymal transition (EMT), in which epithelial cells loose cell-cell contacts, cell polarity, acquire mesenchymal-gene expression and down-regulate epithelial-associated genes. EMT program dissociates cells from epithelial sheets into individual cells exhibiting multiple mesenchymal attributes and heightened invasiveness. [10] EMT has also been associated with stem-cell phenotype and resistance to apoptosis. Consequently, CTCs with EMT phenotype are more capable of survival in different environments (e.g. blood stream) and are more proficient colonising distant sites. [11] It was shown that induction of EMT in mammary epithelial cells results in acquisition of stem-cell properties (e.g. chemoresistance) and conversely, reversing EMT (that is mesenchymal-to-epithelial transition (MET)), leads to sensitisation of cancer stem cells to cancer treatment. [12] EMT switch is associated with enhanced migration, cell adhesion facilitating extravasion and neovasculogenesis. Several extracellular molecules induce EMT (e.g. Notch, TGF- $\beta$, Wnt), which relay signals intracellularly through 
MAPK, PI3K, NF- $\kappa B$ and others to act on transcription factors such as Snail, Slug, Twist, SIP1 and others. Consequently, several EMT genes are downregulated (E-cadherin, cytokeratin, Claudins) and mesenchymal markers upregulated (N-cadherin, vimentin, MMPs, collagens). [13] In humans, EMT phenotype was detected in several cancers and studies have also reported reduced expression of epithelial markers and increase in mesenchymal gene expression on breast cancer CTCs. [14-17] Blocking expression of Twist in 4T1 mammary cell line reduced metastatic burden and CTCs in mice with these xenograft tumors, linking EMT, CTCs and presence of metastasis. [18] Another elegant study used dynamic in vivo model of EMT using vimentin as a marker of mesenchymal phenotype. Clear heterogeneity of vimentin in the primary tumor was observed and CTCs in blood of mice were detected as early as day 8 after inoculation. Vimentin was expressed in the CTCs from all mice, however Snail and Slug expression was found in minority of samples. Intravascular tumor emboli also expressed vimentin, suggesting EMT phenotype is associated with intravasation and formation of CTCs. [19] In large lung metastases, vimentin expression was again heterogeneous with homogenous expression of E-cadherin, as in primary tumors. It is thought that following extravasation and in the colonisation process, CTCs undergo re-differentiation to an epithelial phenotype and form colonies with similar characteristics as primary tumor. It is possible that in this transformation process, some CTCs might keep their mesenchymal and stem-cell properties. This is supported by the fact that emboli in the lungs in previous experiment still expressed vimentin, suggesting that some EMT characteristics remain during extravasation, but MET occurs for further metastatic growth. Further data to support the role of EMT in the dissemination of human breast cancer come from the work of Yu et al. [20] Rare primary tumor cells exhibiting both epithelial and mesenchymal markers were identified, and serial monitoring of CTCs with mesenchymal phenotype was associated with disease progression. These cells were expressing known EMT regulators, such as TGF- $\beta$ and FOXC1 transcription factors.

Intravasation and survival in circulation. Intravasation of invasive cells is influenced by various humoral factors, such as transforming growth factor- $\beta$ (TGF $\beta$ ), epidermal growth factors from tumor-associated macrophages and vascular endothelial growth factors (VEGFs). The neovasculature generated by carcinoma is abnormal, lacks extensive pericyte coverage and no longer provides a physical barrier that would restricts transendothelial cancer cell intravasation. [21] CTCs in circulation are challenged by hostile environment - hemodynamic forces, immune cells (e.g. natural killer cells) and absence of adhesion to ECM, which is essential for epithelial cells. Normally, epithelial cells undergo anoikis, a form of apoptosis activated by loss of adhesion to ECM. On the other hand, it is likely that CTCs spend only a brief time in circulation owing to their large size compared to capillaries. [6] Additionally, carcinoma cells form large tumor emboli by interaction with blood coagulation system and platelets. The binding of tumor cells through tissue factors, fibrin, L- and P-selectins to platelets enables them to shield themselves from physical forces in blood stream, evade immune system and lodge themselves as tumor microemboli.

Kim et al. observed in breast and colon xenograft models re-infiltration of primary tumor by cells from its metastatic sites, a process called "self-seeding". [22] Self-seeding requires ability of primary tumor to attract its CTCs and CTCs to be able to re-infiltrate primary tumor site. It is also possible that re-infiltrating CTCs may provide growth advantage to primary tumor by changing its metastasis virulence genes (these genes CTCs acquired/accumulated at distant sites).

Arrest and colonisation. Theoretically, CTCs can disseminate to any site given the anatomical layout of vasculature. Still, it has been observed in the clinic that certain cancers metastasise to only a limited subset of target organs. Certainly, some CTCs are capable of specific adhesive interactions, such as metadherin expression on breast cancer cells homing to lungs. [23] In order to extravasate, CTCs secrete various factors inducing vascular permeability and disrupting endothelial cell-cell junctions in healthy microvasculature. For example, MMP-1 and MMP-2, as well as angiopoietin-like-4 and cyclooxygenase-2 (COX-2) disrupt pulmonary vasculature for breast CTCs to extravasate in lung parenchyma. [24] Tumor cells can also express chemokine receptors that guide tumor cells to specific sites. [25] Psaila at al. have argued for establishment of "premetastatic niche" whereby hematopoietic progenitor cells from bone marrow are mobilised by primary tumor signals and interact with fibronectin at future metastatic sites. They further modify local microenvironment through secretion MMP-9 that liberates chemoattractant molecules from ECM (e.g. stromal cell-derived factor-1). [26]

Metastasis formation. Large number of CTCs can be detected in the bloodstream of cancer patients. [27] However, vast majority of CTCs do not form metastatic foci, a point demonstrated by 15 ovarian cancer patients with peritoneovenous shunts for malignant ascites. These patients received millions of cancer cells into their circulation, but failed to develop overtly metastatic disease. On autopsy, some patients did not have any metastases, others have small tumor deposits in many organs and some have more metastatic foci only in organs already involved prior to placement of shunt. [28] These data suggest that for CTCs, only very few complete all steps of metastatic cascade and form macroscopic metastases. In some patients with breast carcinoma, late relapses, often decades after primary surgery, have been observed. This could be explained by cell dormancy, gradual accumulation of genetic and/or epigenetic changes required for colonisation or by changes in microenvironment.

\section{CTCs in breast cancer}

Presence of CTCs in peripheral blood represent surrogate marker for tumor self-seeding potential. They play pivotal 
role in tumor progression and dissemination. The detection, enumeration and characterisation of CTCs should guide clinicians about cancer prognosis, help in prediction of treatment effectiveness and provide superior method for detection of disease progression. Furthermore, ability to identify subpopulation of CTCs with stem-cell properties should direct targeted treatments and affect metastatic cascade. [29] There are several challenges in detection and characterisation of CTCs. They represent rare cells in the background of millions of nucleated blood cells; therefore enrichment step is needed before detection of CTCs. However, due to its heterogeneity, preselected marker for enrichment will not detect CTCs without this marker, i.e. CTCs with mesenchymal phenotype will be missed if they do not express selected epithelial marker. Lastly, there is a limitation on blood volume that can be taken from a patient in view of increasing yield of CTCs. CTCs were initially described almost 150 years ago as cancer cells in blood of deceased patient. [30] More than 50 platforms have been used for detection of CTCs; the only FDA-cleared system is CellSearch from Veridex, USA. Table 1 gives overview of some commercially available or frequently used systems.

A novel method of detecting CTCs in vivo is being developed. A GILUPI CellCollector is antibody (e.g. antiEpCAM-antibody) coated wire inserted into cubital vein of patient for 30 minutes, thereby coming into contact with large volume of patient blood. Following enrichment, further CTCs detection is carried out by various methods (immunocytologicaly, in vivo cell culture (EPISPOT) or using molecular technologies). Common method of enrichment is based on immunomagnetic isolation. Usually, magnetic beads are labelled with antibodies specific for EpCAM (epithelial adhesion molecule) for positive selection and anti-CD45 antibody (anti-leukocyte) for negative selection. Labelled cells are then separated by strong magnetic fields. This method is used in FDA-approved CellSearch system for CTC detection. However, this technology may miss cells that do not express selected antigens. Although negative selection might abrogate this, additional processing (e.g. red cell lysis) may lead to further loss of CTCs. Several other platforms use antibodies (EpCAM) immobilised on solid-surfaces (e.g. CTC-chip) and combine these with filtration methods (e.g. On-Q-ity Chip). Further enhancement of CTC capture efficiency was studied using P-/E-selectin in addition to EpCAM selection. More than 3-fold enhancement of CTC selection was by described using these additional adhesion molecules. [31] Another methods use filtration based on size of cells and their deformability - more deformable erythrocytes and leucocytes pass via small $(5 \mu \mathrm{m})$ gaps, but stiffer and larger tumor cells are tapped. Combination of anti-EpCAM selection, sedimentation and microfiltration was described as having recovery rate up to $99 \%$ for MCF-7 cancer cells. [32] Comparison of various commercial platforms for CTC detection was performed. [33-35] CytoTrack (laser scanning of labelled cells) and CellSearch (EpCAM based) systems showed comparable ability to identify CTCs in vitro with a recovery rate of almost $70 \%$ for MCF-7 cells. CellSieve method (a microfiltration system) isolated larger population of $\mathrm{CK}+/ \mathrm{CD} 45$ - cells than CellSearch. Using nuclear morphology and specific CK staining pattern, a distict subpopulation of CTCs correlated with that found by CellSearch. AdnaTest BreastCancer Select/Detect (detection of gene transcripts GA 733-2, MUC-1 and HER2) showed equivalent sensitivity to that of CellSearch system in detecting $>2$ CTCs. AdnaTest complements the CellSearch system in allowing assessment of genomic markers. In CellSearch system, cytokeratin and DAPI-positive, CD45-negative cells are enumerated semiautomatically using fluorescent microscope. In AdnaTest BreastCancer Select/Detect, mRNA is isolated from selected cells (based on magnetic particles), transcribed into cDNA and subjected to multiplex PCR for tumor-associated gene expression. If cells are isolated by size, they are further stained by CK-antibodies and specific surface markers for that particular tumor. Enumeration is done by light or fluorescent microscopy. All these different technologies might detect different CTCs populations. Analytical validity (accuracy of

Table 1. Platforms for capture of CTCs

\begin{tabular}{|c|c|}
\hline \multicolumn{2}{|l|}{ EpCAM-affinity based } \\
\hline CellSearch system & Iron particles with CTCs removed by magnets. DAPI+ (nuclear staining), CK8,18,19+, CD45-, $4 \mu \mathrm{m}$ in size \\
\hline AdnaTest & Antigen selection and further RT-PCR analysis for tumor associated genes (EpCAM, MUC-1, HER-2) \\
\hline On-Q-ity Chip & Microfabricated columns coated with EpCAM antibodies and gradient sizing \\
\hline $\begin{array}{l}\text { MACS (magnetic activated cell sorting } \\
\text { system) }\end{array}$ & Magnetic beads with anti-EpCAM or tumor epitopes \\
\hline \multicolumn{2}{|l|}{ Physical properties-based } \\
\hline Density gradient centrifugation & Heavier neutrophils and erythrocytes migrate to bottom, tumor cells and mononuclear cells are at top \\
\hline ScreenCell & Filtration based on cell size \\
\hline ApoStream & Uses electrical property differentiation between normal blood and tumor cells \\
\hline DEPArray & Electrical property differentiation. Image-based selection \\
\hline \multicolumn{2}{|l|}{ Others } \\
\hline EPISPOT (Epithelial immunospot) & Depletion of CD45+, enrichment of CXCR4+ cells, ELISA based detection of secreted proteins, viable cells only \\
\hline $\begin{array}{l}\text { FAST (Fibre-optic array scanning } \\
\text { technology) }\end{array}$ & Ultra-fast digital microscopy detecting immunofluorescently labelled cells 500x faster than digital microscopy \\
\hline
\end{tabular}


measurement) of these tests is challenging. Indeed, characterization of CTCs in respect to EMT is also a challenge - there are no specific molecular markers, mesenchymal markers (e.g. vimetin) might lead do high false positive results and selection based on epithelial markers would be unsatisfactory. [19] CTC enrichment limited to EpCAM positive cells may miss CTCs that do not present this specific marker, such as those with EMT phenotype. Several signaling pathways are responsible for EMT, such as TGF $\beta$, Wnt, Notch and others. They induce transcriptional factors such as Snail-1, Slug, Twist, ZEB1, 2 and others. Twist1, in cooperation with BMI1, promotes cancer dedifferentiation and metastasis. [36] For example, commercially available AdnaTest EMT/StemCellDetect detects TWIST1, Akt-2 and PI3Ka transcripts and contains primer for stem-cell detection, ALDH1. Several authors used detection of CTC subpopulations with AdnaTest or other mesenchymal markers (vimentin, N-cadherin, SNAIL). [15, 37-40] Collectively, they found that CTCs are not uniform population; they can co-express one or both markers and exist in transitional state from epithelial to mesenchymal phenotype. Furthermore, clinical validity of CTCs is only recently being explored by several trials. CTC enumeration is supported as prognostic marker in breast cancer and its role as predictive biomarker is promising. [41-44]

Prognostic role of CTCs. A cut-off $\geq 5$ CTCs in $7.5 \mathrm{ml}$ of patient blood was used in pivotal study on 177 women with metastatic breast cancer before starting new line of chemotherapy and at the first follow-up visit. Patients with higher than 5 CTCs had shorter median PFS and OS (2.7 vs 7 months and $10.1 \mathrm{vs}>18$ months, $\mathrm{p}<0.001$ ). [41] Increased in survival of patients with $<5$ CTCs in blood was independent of histology, HR status, molecular subtype, line of treatment or whether patient had recurrent or newly diagnosed metastatic disease. CTCs analysed at mid-treatment in retrospective analysis were compared with metabolic response using 18-FDG PET/CT scanning. Detection of five or more CTCs during treatment accurately predicted prognosis of metastatic breast cancer patients beyond metabolic response. [45] Prognostic usefulness was further confirmed in two large retrospective analyses. Six studies totalling 841 patients predicted for worse PFS and OS at baseline and at various time points up to 21 weeks from initiation of anticancer treatment independently of type or line of chemotherapy and site of metastases. [46] Another pooled analysis compiled 1944 patients starting new line of treatment and having CTC quantification done by validated CellSearch method. This study also confirmed independent prognostic effect of CTC count on PFS and OS. Moreover, increases in CTCs during treatment were associated with shortened survival and conversely, decreases in CTCs with treatment prolonged PFS and OS. [47] Given these data, serial CTCs enumeration could be used as a surrogate marker for patient prognosis. Recent publication also confirmed value of CTCs in newly diagnosed inflammatory breast cancer. [48] Data are less clear in patients undergoing targeted treatment. It is thought that antiangiogenic compounds interfere with
CTCs extravasation or induce EMT phenotype, rendering CTCs enumeration difficult. $[49,50]$ Prognostic role of CTCs during treatment with HER-2 targeted agents is inconsistent. It is plausible that effective anti-HER-2 treatment eliminates CTCs bearing HER-2 amplification. [51, 52]

A cut-off $\geq 1$ CTCs in $7.5 \mathrm{ml}$ of patient blood was set for early stage breast cancer. [44] CTCs were detected in approximately $20 \%$ of patients in adjuvant setting in a large multicenter prospective German study (SUCCESS). Patients with lymph node metastases were more often CTC positive but other clinicopathologic characteristics or treatment were not associated with CTC positivity. There was no difference in CTC count before and after chemotherapy. The presence of CTCs was significantly predictive of reduced three year disease-free survival (DFS) at $87.9 \%$ vs $94.2 \%$ for CTC negative patients, $\mathrm{p}<0.001$. It is interesting to note that in subgroup analysis, presence of CTCs reduced DFS in all node positive patients, but not in node negatives. [53] Presence of CTCs was associated with reduced breast-cancer specific and overall survival. Also, persistence of CTCs after adjuvant chemotherapy was significantly associated with reduced DFS and with trend toward reduced OS. This fact might be relevant in the clinic, CTCs persistence might select patients whose tumors are resistant to standard cytotoxic adjuvant chemotherapy. Another prospective study on 302 early breast cancer patients reached similar conclusions. One or more CTCs were identified in $24 \%$ patients, and their presence predicted worse PFS and OS. [44] In a pooled analysis of 3172 early stage patients, CTCs were detected in $20 \%$ and associated with larger tumors, lymph node positivity and higher grade. CTCs remained independent prognostic factor in multivariate analysis for poor PFS (HR 1.8) and OS (HR 2.1, p $<0.001$ both). [54]

Predictive role of CTCs. There are several trials on-going investigating treatment tailoring based on CTCs (Table2). [55] Characterisation of CTCs properties could lead to useful predictive biomarkers and would represent real-time biopsies in cancer patients undergoing treatment.

SWOG S0500 is first prospective trial with reported results evaluating whether early treatment switch based on persistence of CTCs would improve outcome. One hundred twenty three patients with $\geq 5$ CTCs $/ 7.5 \mathrm{ml}$ blood that persisted after one cycle of first-line chemotherapy were randomised to continue initial treatment until radiographic progression or to change treatment (physician choice). Changing treatment based on persistence of CTCs did not improve their OS (HR 1.0). Lack of effective treatment options for these patients might be plausible explanation. These patients might be better served by molecular analysis of CTCs and determination whether patients are eligible for trial with targeted treatment. Prognostic value of CTCs was confirmed: median OS of 35 months was seen in patients with low CTCs prior starting chemotherapy, compared to only 13 months for those with persistent high counts. Patients whose elevated CTCs dropped after one cycle of chemotherapy had intermediate prognosis with OS of 23 months $(\mathrm{p}<0.001)$. [56] 
Table 2. Selected randomized trials evaluating clinical utility of CTCs

\begin{tabular}{|c|c|c|c|c|c|}
\hline Trial & Setting & Objective & $\begin{array}{l}\text { No. of patients } \\
\text { planned }\end{array}$ & Results & $\begin{array}{l}\text { Country } \\
\text { Reference }\end{array}$ \\
\hline SWOG 0500 & $\begin{array}{l}\text { MBC, } \geq 5 \text { CTCs } / 7.5 \mathrm{ml} \text { blood before } \\
\text { and after } 1 \text { cycle of } 1^{\text {st }} \text { line chemo }\end{array}$ & $\begin{array}{l}\text { Compare OS between early switch vs } \\
\text { waiting for radiological progression }\end{array}$ & $\begin{array}{l}595 \text { eligible, } \\
123 \text { randomised }\end{array}$ & No change in OS & $\begin{array}{l}\text { USA } \\
{[56]}\end{array}$ \\
\hline $\begin{array}{l}\text { STIC CTC } \\
\text { METABREAST }\end{array}$ & $\begin{array}{l}\text { MBC, ER }+, \text { HER- } 2-, 1^{\text {st }} \text { line HT if } \\
\mathrm{CTC}<5 \text { or chemo if } \geq 5\end{array}$ & $\begin{array}{l}\text { Compare PFS and economic impact be- } \\
\text { tween physician choice and CTC-driven } \\
\text { choice of treatment }\end{array}$ & 994 & on-going & $\begin{array}{c}\text { France } \\
\text { [57] }\end{array}$ \\
\hline COMETI P2 & MBC, ER+, HER-2-, $2^{\text {nd }}$ line of HT & $\begin{array}{l}\text { Observational study of endocrine therapy } \\
\text { index and its impact on radiographic pro- } \\
\text { gression and PFS }\end{array}$ & 200 & on-going & $\begin{array}{c}\text { USA, Canada } \\
\text { [58] }\end{array}$ \\
\hline CirCe01 & $\begin{array}{l}\text { MBC, ER+, HER-2-, } 3^{\text {rd }} \text { line of } \\
\text { chemo }\end{array}$ & $\begin{array}{l}\text { Compare OS between early switch vs wait- } \\
\text { ing for radiological progression }\end{array}$ & 568 & on-going & $\begin{array}{c}\text { France } \\
\text { [59] }\end{array}$ \\
\hline Detect III & $\begin{array}{l}\text { MBC, HER-2-, up to } 3^{\text {rd }} \text { line of } \\
\text { chemo, } \geq 1 \text { HER- } 2+\text { CTC } / 7.5 \mathrm{ml} \text { blood }\end{array}$ & $\begin{array}{l}\text { CTC clearance rate with addition of lapatinib } \\
\text { to chemotherapy in HER- } 2+\text { CTC }\end{array}$ & 120 to randomise & on-going & $\begin{array}{l}\text { Germany } \\
\quad[60]\end{array}$ \\
\hline Detect IV & $\begin{array}{l}\text { MBC, } \geq 1 \text { CTCs } / 7.5 \mathrm{ml} \text { blood, ER+, } \\
\text { HER-2-, for everolimus } \\
\text { or for eribulin ER-, HER-2- }\end{array}$ & $\begin{array}{l}\text { Impact on PFS with addition of } \\
\text { everolimus to HT or eribulin }\end{array}$ & 520 & on-going & $\begin{array}{l}\text { Germany } \\
\quad[61]\end{array}$ \\
\hline Treat-CTC & $\begin{array}{l}\text { EBC, } \geq 1 \text { CTCs } / 15 \mathrm{ml} \text { blood, HER-2- } \\
\text { post chemo }\end{array}$ & $\begin{array}{l}\text { Compare CTC detection after } 18 \text { wks of } \\
\text { treatment with trastuzumab vs observation }\end{array}$ & 174 to randomise & on-going & $\begin{array}{l}\text { EORTC } \\
{[62]}\end{array}$ \\
\hline
\end{tabular}

In the French STIC CTC trial, almost $1000 \mathrm{MBC}$ patients that express HR and are negative for HER-2 are planned to accrue. Randomisation will be between standard arm of physician choice of hormone treatment or chemotherapy based on current guidelines versus CTC arm where patients with low CTC $(<5$ cells $/ 7.5 \mathrm{ml})$ will be treated with less aggressive approach (hormone treatment) and those with $\geq 5$ cells $/ 7.5 \mathrm{ml}$ will receive chemotherapy. This trial has been designed to show non-inferiority of CTC arm for PFS and superiority of CTC arm for medico-economics endpoints. [57] Preliminary results (presented as oral congress communication, Crete, 2014) showed that in 33\% patients randomised in investigational arm, CTC level determination led to a change of treatment.

COMETI P2 is on-going study in North America that is taking into consideration not only CTC count but also the biology of CTC. Four biomarkers are assessed on isolated CTCs in the CellSearch system: ER, Bcl2, HER-2 and Ki67. An endocrine therapy index (ETI) score is calculated based on number of CTCs and staining intensity of these four biomarkers. Two hundred patients proceeding to second line HT will be observed for early radiographic progression and PFS and these time points will be correlated to their endocrine therapy index score. It is hypothesised that CTC-ETI will be predictive of endocrine responsiveness or resistance. [58]

The French CirCe01 is another attempt to compare early switch of chemotherapy in non-responding patients based on elevated CTCs after first cycle of chemotherapy. Moreover, CTCs will be evaluated after first cycle of each new line of chemotherapy treatment. Patients with persistently elevated CTCs will change chemotherapy after only one cycle of therapy. Standard arm will involve radiological and clinical assessments for progression. [59] It is hoped that early discontinuation of useless chemotherapies in this very palliative setting will bring palliative care to patients sooner and also reduce treatment costs.

DETECT III trial is evaluating addition of lapatinib, a HER-2 targeting agent, to conventional treatment in initially HER-2 negative MBC (on biopsy) who have at least one CTC that is HER-2 positive. As HER-2-negative primary tumors can develop HER-2-positive CTCs during progression from 9-24\%, a question is if these patients will benefit from anti-HER-2 targeted treatments. $[63,64]$ The study primary endpoint was recently modified from PFS (and randomisation of over 200 patients) to clearance of CTCs with only 120 patients need to be randomised. [60] A spin-off study DETECT IV is recruiting patients those are HER-2 negative and have HER-2 negative at least $1 \mathrm{CTC} / 7.5$ blood. These patients are then assigned to addition of everolimus to endocrine treatment (if HT would be their treatment otherwise) or newly approved drug eribulin to those who would be considered for cytotoxic treatment. PFS of both groups is primary endpoint. [61]

EORTC trial Treat-CTC is investigating addition of adjuvant trastuzumab to women with HER-2 negative tumors who have completed assigned adjuvant chemotherapy and still have persistent CTCs (so called cM0(i+) patients). They are randomised to observation (standard arm) or addition of anti-HER-2 targeted treatment. After six courses CTC count is repeated and compared. Recurrence-free survival is secondary endpoint. [62] The rationale comes from several observation; benefit of adjuvant trastuzumab might not be confined to HER-2 overexpressing tumors (as seen in subgroup analysis from NSABP B31 and N9831 trials), and mouse models suggesting trastuzumab might target cancer stem-cell population. $[65,66]$ Further evidence for efficacy comes from randomised phase II study where HER-2 negative EBC patients with persistent CTC that were 
double stained for CK+/HER-2+ with CK 19+ mRNA. DFS was significantly higher for trastuzumab treated patients $(\mathrm{p}=0.008)$. [67]

These trials represent attempts to definite a place for CTC testing in clinical practice in early and metastatic breast cancer patients. Each of them proposes different, complementary design that will guide further research into this new biological tool with hope to improve lives of breast cancer patients.

\section{Potential biomarkers in primary tumor associated with CTCs}

Although clinical utility of CTCs enumeration is being recognised in various trials, in future CTCs might provide "liquid biopsy" for molecular screening programs and treatment tailoring. Whole-exome sequencing and NGS have already been explored, as well as drug-sensitivity testing of cultured CTCs ex vivo. [68-70] Currently, clinically useful tissue biomarkers in primary breast tumor are hormonal receptor status (ER, PR), HER-2, proliferation index Ki-67 and grade of the tumor, other factors are clinical - extent of disease, its localisation, patient age and performance status. CTCs would present a unique biomarker, as they represent part of patient's tumor burden that could be assessed for target antigens. Moreover, their phenotypic properties might be associated with specific biomarkers in primary tumors that lead to more aggressive behaviour of cancer.

In two prospective studies evaluating (repeated) biopsies of metastatic disease, discordance rates between primary tumor (removed previously) and new metastases were about $10 \%$ for HER-2 and 10-16\% for ER. These biopsies brought change of treatment in $14-18 \%$ of patients. [71, 72]

HER-2. Evaluation of HER-2 on CTCs is possible through the use of spare channel of the CellSearch system. HER-2 positive CTCs were reported from $24-33 \%$ in studies evaluating CTCs in neoadjuvant setting and in metastatic disease. [73, 74] Concordance of HER-2 status between primary tumor and baseline was $86-87 \%$ for HER-2 negative or positive primary tissue, respectively. Overall, $18 \%$ of patients acquired HER-2 positivity during treatment. Generally, presence of HER-2 positive CTCs was associated with inferior outcomes compared to HER-2 negative or no CTCs. Ligthart et al. in prospective study evaluating HER-2 CTCs in adjuvant and metastatic patients defined CTCs HER-2 positivity as overexpression in $75 \%$ of CTCs with $\geq 5$ CTCs. Using this cut-off, $9 \%$ of M1 patients that were HER-2 negative had HER-2 positive CTC status and conversely $29 \%$ with HER-2 positive primary had negative HER-2 CTCs. [64] As detailed above, HER-2 evaluation on CTCs and its impact on patient management is being further studied in clinical trials.

ER, PR. ER and PR receptors are established biomarkers in breast cancer, however only $30 \%$ respond to HT in registration studies of aromatase inhibitors. [75, 76] Heterogeneous populations of CTCs with different hormonal phenotypes were described in breast cancer patients. [77] Primary breast tumors are classified as ER positive if at least $1 \%$ of cells stain on immunohistochemical investigation. Thus, ER-negative CTCs might originate from ER-negative (primary) cells, or these clones might be selected under pressure from hormonal therapy. This CTC heterogeneity might be partly responsible for failure of HT. Fifty percent of CTCs showed mixture of both ER positivity and ER-negativity in ER-positive primary tumor. In the same study ER-negative CTCs were found in $19 \%$ of patients harbouring ER-positive primary tumor. [78] By culturing CTCs ex vivo and establishing CTC-derived cell lines, it was possible to identify activating ESR-1 mutations in three of six CTCs lines from pre-treated patients with aromatase inhibitors. These ESR-1 mutant cell lines were resistant to tamoxifen and fulvestrant, but resistance was overcome by HSP90 inhibitor. [70] Discordance rates between primary tumor and ER positive CTCs vary from $40-77 \%$ in some studies. These wide variations might be also due to methodological issues, differences in cut-off limits for ER/PR receptors in CTCs as well as primary samples. $[79,80]$

Other biomarkers. Other potential biomarker that was already detected in cultured CTCs is PIK3CA, alpha catalytic subunit of phosphatidylinositol 3-kinase. PIK3CA mutations are frequent mutations in breast cancer; up to $21 \%$ were detected in 504 samples from German neoadjuvant studies. It was demonstrated that these patients are less likely to achieve pCR rates with neoadjuvant chemotherapy and trastuzumab. [81] Analysis of PI3K pathways markers could influence patients for selection of PI3K/AKT/mTOR pathway inhibitors. Detection of PIK3CA was also achieved from circulating free DNA, when these samples were compared to up-to-date tumor biopsies, concordance rate of $100 \%$ was detected. If comparison was done on archived tumor tissue, discordance rate rose to $30 \%$. [82] These results suggest that trials investigating PIK3CA inhibitors should optimally select patients on current mutational status rather than on archival tissue. PIK3CA mutations were detected in 35\% of CTCs by combination of allele-specific, asymmetric rapid PCR and melting analysis. [83] It was also confirmed in this study that PIK3CA mutation status can change during disease progression and is associated with inferior survival. Evaluation of PIK3CA in CTCs appears to be clinically plausible strategy, however with a caveat that there may be a mutational heterogeneity within one sample or at different time points. [84]

Evaluation of phospho-PI3K, along with EGFR, HER-2 and phospho-Akt in early and metastatic breast cancer patients revealed similar levels of phospo-PI3K and phospho-Akt in both disease subgroups. Phospho-EGFR was observed in higher percentage in metastatic patients (33 vs $86 \%$ ). [85] Furthermore, it was found out that EGFR is co-expressed with HER-2 and both phospho- kinases. This pathway could be used as a target for novel agents.

Another potential biomarker that is currently under study is TOP2A, a DNA topoisomerase II alpha. Amplifications in TOP2A gene were associated with responsiveness to anthracycline (DNA topoisomerase 2 inhibitor) chemotherapy. TOP2A amplifications was analysed in one study on 
CTCs. Concordance rates were around $70 \%$ and no HER-2 co-amplification was detected in CTCs. After three cycles of anthracycline treatment, co-amplification of TOP2A and HER-2 was detected in one patient with initially negative tumor for both of these markers. [77] Such changes might be clinically relevant, as patients with co-amplifications of HER-2 and TOP2A may benefit with anti-HER agents and anthracycline-based regiments.

Expression of Notch ligands (Delta-like and Jagged) has been reported in triple-negative breast cancer and blocking agents this signalling pathway have entered development. Similarly, inhibitors of other signalling pathways involved in breast cancer tumorigenesis, such as Hedgehog and Wnt have entered development. Other potential biomarkers might include multidrug resistance-associated protein (MRP), which is related to more aggressive behaviour and resistance to treatment and IGF-1 and IGF-1R (insulin growth factor receptor), related to radioresistance and local recurrence. [86, 87] Recent study has investigated MMP1 expression in primary tumors and phenotypic changes in CTCs. In multivariate analysis, CTCs with EMT phenotype and tumor grade were associated with MMP1 expression in cancer cells, while Ki-67 and CTCs with EMT phenotype were independently associated with MMP1 expression in tumor associated stroma. [88] Other potential marker associated with tumor expansion is VEGF, vascular endothelial growth factor. Overexpression of VEGFs produces cell proliferation and changes in tumor vasculature and would facilitate CTC release. Interleukin- 8 and its cognate receptors, CXCR1 and CXCR2 are important in regulating breast cancer stem-like cells. IL-8 activates EGFR and HER-2 and is associated with poor prognosis in breast cancer. [89] Fibroblast growth factors and their receptors (FGFR) promote several steps in metastatic pathway, including EMT, invasion and angiogenesis. [90] Recently truncated FGFR1- $\beta$ splice variant was identified in cell cultures after exposure to TGF- $\beta$ and same variant was confirmed on patient-derived tumor samples. Its expression was important in metastatic outgrowth. [91] Other potential markers associated with CTCs might be vimentin (as described in previous section), fibronectin, claudin-4, SPARC, CAIX, Plastin3 and Glut-1. [92] Aurora-A kinase has also been implicated in EMT pathway responsible for the development of distant metastases in $\mathrm{ER} \alpha(+)$ breast cancer cells. [93]

However, data that show clinical utility of these biomarkers are yet unavailable. Clinical utility will also depend on prevalence of patients in whose such an approach would be feasible.

\section{Conclusions}

Despite heterogeneity of breast cancer, current therapeutic strategies are based on the samples from primary tissues. Few validated biomarkers exist that guide our treatment decisions. Many patients with seeming good prognosis (small tumors, no lymph node involvement) that are treated less aggressively in adjuvant setting recur, on the other hand it is possible that we are over treating substantial majority of women in adjuvant setting. Circulating tumor cells represent promising biomarker in personalising treatment for cancer patients. CTCs have already demonstrated its prognostic value in several trials in early as well as advanced breast cancer. Validation of assays for CTCs bearing certain biomarkers would be clinically useful in term of diagnosis, prognosis and therapy failure. Randomised clinical trials with standardised methodologies are urgently needed. Besides established therapeutic targets (ER, HER2) and other potential markers present on CTCs (PIK3CA), other markers involved in metastatic cascade and self-seeding should be further identified with their relation to CTCs. Interruption of metastatic cascade on several levels, targeting CTCs as well as biomarker-driven phenotype of primary tumor might significantly change outcome of breast cancer patients.

\section{References}

[1] FERLAY J, SOERJOMATARAM, I., ERVIK, M., DIKSHIT, R., ESER, S., MATHERS, C., REBELO, M., PARKIN, D.M., FORMAN, D., BRAY, F. GLOBOCAN 2012 v1.0, Cancer Incidence and Mortality Worldwide: IARC CancerBase No. 11 [Internet]. Lyon, France: International Agency for Research on Cancer; 2013 Available from: http: //globocan. iarc.fr, accessed on 13.1. 2015.

[2] DESANTIS C, MA J, BRYAN L, JEMAL A. Breast cancer statistics, 2013. CA Cancer J Clin 2014; 64: 52-62. http://dx.doi. org/10.3322/caac. 21203

[3] CHIA SK, SPEERS CH, D'YACHKOVA Y, KANG A, MALFAIR-TAYLOR S, et al. The impact of new chemotherapeutic and hormone agents on survival in a population-based cohort of women with metastatic breast cancer. Cancer 2007; 110: 973-979. http://dx.doi.org/10.1002/cncr.22867

[4] RUSSNES HG, NAVIN N, HICKS J, BORRESEN-DALE AL. Insight into the heterogeneity of breast cancer through nextgeneration sequencing. J Clin Invest 2011; 121: 3810-3818. http://dx.doi.org/10.1172/JCI57088

[5] APARICIO S, CALDAS C. The implications of clonal genome evolution for cancer medicine. N Engl J Med 2013; 368: 842-851. http://dx.doi.org/10.1056/NEJMra1204892

[6] VALASTYAN S, WEINBERG RA. Tumor metastasis: molecular insights and evolving paradigms. Cell 2011; 147: 275-292. http://dx.doi.org/10.1016/j.cell.2011.09.024

[7] WONG CW, LEE A, SHIENTAG L, YU J, DONG Y, et al. Apoptosis: an early event in metastatic inefficiency. Cancer Res 2001; 61: 333-338.

[8] FRIEDL P, WOLF K. Tumour-cell invasion and migration: diversity and escape mechanisms. Nat Rev Cancer 2003; 3: 362-374. http://dx.doi.org/10.1038/nrc1075

[9] MENG S, TRIPATHY D, SHETE S, ASHFAQ R, SABOORIAN $\mathrm{H}$, et al. uPAR and HER-2 gene status in individual breast cancer cells from blood and tissues. Proc Natl Acad Sci U S A 2006; 103: 17361-17365. http://dx.doi.org/10.1073/ pnas. 0608113103 
[10] THIERY JP, ACLOQUE H, HUANG RY, NIETO MA. Epithelial-mesenchymal transitions in development and disease. Cell 2009; 139: 871-890. http://dx.doi.org/10.1016/j. cell.2009.11.007

[11] MANI SA, GUO W, LIAO MJ, EATON EN, AYYANAN A, et al. The epithelial-mesenchymal transition generates cells with properties of stem cells. Cell 2008; 133: 704-715. http:// dx.doi.org/10.1016/j.cell.2008.03.027

[12] MEGO M, MANI SA, CRISTOFANILLI M. Molecular mechanisms of metastasis in breast cancer--clinical applications. Nat Rev Clin Oncol 2010; 7: 693-701. http://dx.doi. org/10.1038/nrclinonc. 2010.171

[13] BONNOMET A, BRYSSE A, TACHSIDIS A, WALTHAM M, THOMPSON EW, et al. Epithelial-to-mesenchymal transitions and circulating tumor cells. J Mammary Gland Biol Neoplasia 2010; 15: 261-273. http://dx.doi.org/10.1007/ $\underline{\text { s10911-010-9174-0 }}$

[14] SARRIO D, RODRIGUEZ-PINILLA SM, HARDISSON D, CANO A, MORENO-BUENO G, et al. Epithelial-mesenchymal transition in breast cancer relates to the basal-like phenotype. Cancer Res 2008; 68: 989-997. http://dx.doi. org/10.1158/0008-5472.CAN-07-2017

[15] MEGO M, MANI SA, LEE BN, LI C, EVANS KW, et al. Expression of epithelial-mesenchymal transition-inducing transcription factors in primary breast cancer: The effect of neoadjuvant therapy. Int J Cancer 2012; 130: 808-816. http:// dx.doi.org/10.1002/ijc.26037

[16] RAIMONDI C, GRADILONE A, NASO G, VINCENZI B, PETRACCA A, et al. Epithelial-mesenchymal transition and stemness features in circulating tumor cells from breast cancer patients. Breast Cancer Res Treat 2011; 130: 449-455. http:// dx.doi.org/10.1007/s10549-011-1373-X

[17] KALLERGI G, PAPADAKI MA, POLITAKI E, MAVROUDIS D, GEORGOULIAS V, et al. Epithelial to mesenchymal transition markers expressed in circulating tumour cells of early and metastatic breast cancer patients. Breast Cancer Res 2011; 13: R59. http://dx.doi.org/10.1186/bcr2896

[18] YANG J, MANI SA, DONAHER JL, RAMASWAMY S, ITZYKSON RA, et al. Twist, a master regulator of morphogenesis, plays an essential role in tumor metastasis. Cell 2004; 117: 927-939. http://dx.doi.org/10.1016/j.cell.2004.06.006

[19] BONNOMET A, SYNE L, BRYSSE A, FEYEREISEN E, THOMPSON EW, et al. A dynamic in vivo model of epithelialto-mesenchymal transitions in circulating tumor cells and metastases of breast cancer. Oncogene 2012; 31: 3741-3753. http://dx.doi.org/10.1038/onc.2011.540

[20] YU M, BARDIA A, WITTNER BS, STOTT SL, SMAS ME, et al. Circulating breast tumor cells exhibit dynamic changes in epithelial and mesenchymal composition. Science 2013; 339: 580-584. http://dx.doi.org/10.1126/science.1228522

[21] CARMELIET P, JAIN RK. Principles and mechanisms of vessel normalization for cancer and other angiogenic diseases. Nat Rev Drug Discov 2011; 10: 417-427. http://dx.doi. org/10.1038/nrd3455

[22] KIM MY, OSKARSSON T, ACHARYYA S, NGUYEN DX, ZHANG XH, et al. Tumor self-seeding by circulating cancer cells. Cell 2009; 139: 1315-1326. http://dx.doi.org/10.1016/j. cell.2009.11.025

[23] BROWN DM, RUOSLAHTI E. Metadherin, a cell surface protein in breast tumors that mediates lung metastasis. Cancer Cell 2004; 5: 365-374. http://dx.doi.org/10.1016/ S1535-6108(04)00079-0

[24] PADUA D, ZHANG XH, WANG Q, NADAL C, GERALD WL, et al. TGFbeta primes breast tumors for lung metastasis seeding through angiopoietin-like 4 . Cell 2008; 133: 66-77. http://dx.doi.org/10.1016/j.cell.2008.01.046

[25] MUller A, HOMEY B, SOTO H, GE N, CATRON D, et al. Involvement of chemokine receptors in breast cancer metastasis. Nature 2001; 410: 50-56. http://dx.doi. org/10.1038/35065016

[26] PSAILA B, LYDEN D. The metastatic niche: adapting the foreign soil. Nat Rev Cancer 2009; 9: 285-293. http://dx.doi. org/10.1038/nrc2621

[27] NAGRATH S, SEQUIST LV, MAHESWARAN S, BELL DW, IRIMIA D, et al. Isolation of rare circulating tumour cells in cancer patients by microchip technology. Nature 2007; 450: 1235-1239. http://dx.doi.org/10.1038/nature06385

[28] TARIN D, PRICE JE, KETTLEWELL MG, SOUTER RG, VASS AC, et al. Mechanisms of human tumor metastasis studied in patients with peritoneovenous shunts. Cancer Res 1984; 44: 3584-3592.

[29] CRISTOFANILLI M. Circulating tumour cells: telling the truth about metastasis. Lancet Oncol 2014; 15: 365-366. http://dx.doi.org/10.1016/S1470-2045(14)70091-9

[30] ASHWORTH T. A case of cancer in which cells similar to those in the tumors were seen in the blood after death. Aust Med J 1869; 14: 146-149.

[31] MYUNG JH, GAJJAR KA, SARIC J, EDDINGTON DT, HONG S. Dendrimer-mediated multivalent binding for the enhanced capture of tumor cells. Angew Chem Int Ed Engl 2011; 50: 11769-11772. http://dx.doi.org/10.1002/anie.201105508

[32] PARK JM, LEE JY, LEE JG, JEONG H, OH JM, et al. Highly efficient assay of circulating tumor cells by selective sedimentation with a density gradient medium and microfiltration from whole blood. Anal Chem 2012; 84: 7400-7407. http:// dx.doi.org/10.1021/ac3011704

[33] HILLIG T, HORN P, NYGAARD AB, HAUGAARD AS, NEJLUND S, et al. In vitro detection of circulating tumor cells compared by the CytoTrack and CellSearch methods. Tumour Biol 2015;

[34] ADAMS DL, STEFANSSON S, HAUDENSCHILD C, MARTIN SS, CHARPENTIER M, et al. Cytometric characterization of circulating tumor cells captured by microfiltration and their correlation to the cellsearch ((R)) CTC test. Cytometry A 2015; 87: 137-144. http://dx.doi.org/10.1002/cyto.a.22613

[35] ANDREOPOULOU E, YANG LY, RANGEL KM, REUBEN JM, HSU L, et al. Comparison of assay methods for detection of circulating tumor cells in metastatic breast cancer: AdnaGen AdnaTest BreastCancer Select/Detect versus Veridex CellSearch system. Int J Cancer 2012; 130: 1590-1597. http:// dx.doi.org/10.1002/ijc.26111

[36] YANG MH, HSU DS, WANG HW, WANG HJ, LAN HY, et al. Bmil is essential in Twist1-induced epithelial-mesenchymal 
transition. Nat Cell Biol 2010; 12: 982-992. http://dx.doi. org/10.1038/ncb2099

[37] AKTAS B, TEWES M, FEHM T, HAUCH S, KIMMIG R, et al. Stem cell and epithelial-mesenchymal transition markers are frequently overexpressed in circulating tumor cells of metastatic breast cancer patients. Breast Cancer Res 2009; 11: R46. http://dx.doi.org/10.1186/bcr2333

[38] BARRIERE G, RIOUALLON A, RENAUDIE J, TARTARY M, RIGAUD M. Mesenchymal and stemness circulating tumor cells in early breast cancer diagnosis. BMC Cancer 2012; 12 : 114. http://dx.doi.org/10.1186/1471-2407-12-114

[39] ARMSTRONG AJ, MARENGO MS, OLTEAN S, KEMENY G, BITTING RL, et al. Circulating tumor cells from patients with advanced prostate and breast cancer display both epithelial and mesenchymal markers. Mol Cancer Res 2011; 9:997-1007. http://dx.doi.org/10.1158/1541-7786.MCR-10-0490

[40] PECOT CV, BISCHOFF FZ, MAYER JA, WONG KL, PHAM T, et al. A novel platform for detection of CK+ and CK- CTCs. Cancer Discov 2011; 1: 580-586. http://dx.doi. org/10.1158/2159-8290.CD-11-0215

[41] CRISTOFANILLI M, BUDD GT, ELLIS MJ, STOPECK A, MATERA J, et al. Circulating tumor cells, disease progression, and survival in metastatic breast cancer. N Engl J Med 2004; 351: 781-791. http://dx.doi.org/10.1056/NEJMoa040766

[42] HAYES DF, CRISTOFANILLI M, BUDD GT, ELLIS MJ, STOPECK A, et al. Circulating tumor cells at each follow-up time point during therapy of metastatic breast cancer patients predict progression-free and overall survival. Clin Cancer Res 2006; 12: 4218-4224. http://dx.doi.org/10.1158/1078-0432. CCR-05-2821

[43] NAKAMURA S, YAGATA H, OHNO S, YAMAGUCHI H, IWATA $\mathrm{H}$, et al. Multi-center study evaluating circulating tumor cells as a surrogate for response to treatment and overall survival in metastatic breast cancer. Breast Cancer 2010; 17: 199-204. http://dx.doi.org/10.1007/s12282-009-0139-3

[44] LUCCI A, HALL CS, LODHI AK, BHATTACHARYYA A, ANDERSON AE, et al. Circulating tumour cells in non-metastatic breast cancer: a prospective study. Lancet Oncol 2012; 13 : 688-695. http://dx.doi.org/10.1016/S1470-2045(12)70209-7

[45] DE GIORGI U, VALERO V, ROHREN E, DAWOOD S, UENO NT, et al. Circulating tumor cells and [18F]fluorodeoxyglucose positron emission tomography/computed tomography for outcome prediction in metastatic breast cancer. J Clin Oncol 2009; 27: 3303-3311. http://dx.doi.org/10.1200/JCO.2008.19.4423

[46] LIU M, MEGO, M., NAKAMURA, F., NOLE, F., PIERGA, M. Clinical validity of circulating tumor cell (CTC) enumeration in 841 subjects with metastatic breast cancer (MBC). J CLin Oncol 2011; 29: suppl; abstr 10592

[47] BIDARD FC, PEETERS DJ, FEHM T, NOLE F, GISBERTCRIADO R, et al. Clinical validity of circulating tumour cells in patients with metastatic breast cancer: a pooled analysis of individual patient data. Lancet Oncol 2014; 15: 406-414. http://dx.doi.org/10.1016/S1470-2045(14)70069-5

[48] MEGO M, GIORDANO A, DE GIORGI U, MASUDA H, HSU L, et al. Circulating tumor cells in newly diagnosed inflammatory breast cancer. Breast Cancer Res 2015; 17: 2. http://dx.doi.org/10.1186/s13058-014-0507-6
[49] BIDARD FC, MATHIOT C, DEGEORGES A, ETIENNEGRIMALDI MC, DELVA R, et al. Clinical value of circulating endothelial cells and circulating tumor cells in metastatic breast cancer patients treated first line with bevacizumab and chemotherapy. Ann Oncol 2010; 21: 1765-1771. http://dx.doi. org/10.1093/annonc/mdq052

[50] MEGO M, DE GIORGI, U., HSU, L., DAWOOD, S., Predictive Value of Circulating Tumor Cells (CTCs) in Metastatic Breast Cancer Patients Treated by Bevacizumab-Based Therapy. Cancer Res 2009; 69:

[51] GIORDANO A, GIULIANO M, DE LAURENTIIS M, ARPINO G, JACKSON S, et al. Circulating tumor cells in immunohistochemical subtypes of metastatic breast cancer: lack of prediction in HER2-positive disease treated with targeted therapy. Ann Oncol 2012; 23: 1144-1150. http://dx.doi. org/10.1093/annonc/mdr434

[52] JIANG ZF, CRISTOFANILLI M, SHAO ZM, TONG ZS, SONG EW, et al. Circulating tumor cells predict progression-free and overall survival in Chinese patients with metastatic breast cancer, HER2-positive or triple-negative (CBCSG004): a multicenter, double-blind, prospective trial. Ann Oncol 2013; 24: 2766-2772. http://dx.doi.org/10.1093/annonc/mdt246

[53] RACK B, SCHINDLBECK C, JUCKSTOCK J, ANDERGASSEN U, HEPP P, et al. Circulating tumor cells predict survival in early average-to-high risk breast cancer patients. J Natl Cancer Inst 2014; 106:

[54] JANNI W, BK RACK, LMWW TERSTAPPEN, J-Y PIERGA, T FEHM, C HALL, M GROOT, F-C BIDARD, F MEIERSTIEGEN, TWP FRIEDL, P FASCHING, AND A LUCCI. A pooled analysis of the prognostic relevance of circulating tumor cells in early breast cancer. Cancer Res 2013; 73: suppl; abst PD6-6.

[55] BIDARD FC, FEHM T, IGNATIADIS M, SMERAGE JB, ALIX-PANABIERES C, et al. Clinical application of circulating tumor cells in breast cancer: overview of the current interventional trials. Cancer Metastasis Rev 2013; 32: 179-188. http://dx.doi.org/10.1007/s10555-012-9398-0

[56] SMERAGE JB, BARLOW WE, HORTOBAGYI GN, WINER EP, LEYLAND-JONES B, et al. Circulating tumor cells and response to chemotherapy in metastatic breast cancer: SWOG S0500. J Clin Oncol 2014; 32: 3483-3489. http://dx.doi. org/10.1200/JCO.2014.56.2561

[57] NCT01710605. Medico-economic Interest of Taking Into Account Circulating Tumor Cells (CTC) to Determine the Kind of First Line Treatment for Metastatic, Hormone-receptors Positive, Breast Cancers [Internet]. 2012 Available from: https: //clinicaltrials.gov/ct2/show/NCT01710605, accessed on 13.1. 2015.

[58] NCT01701050. Characterization of Circulating Tumor Cells (CTC) From Patients With Metastatic Breast Cancer Using the CTC-Endocrine Therapy Index (COMETI P2) [Internet]. 2012 Available from: https: //clinicaltrials.gov/ct2/show/ NCT01701050, accessed on 13.1. 2015.

[59] NCT01349842. Circulating Tumor Cells to Guide Chemotherapy for Metastatic Breast Cancer (CirCé01) [Internet]. 2011 Available from: https: //clinicaltrials.gov/ct2/show/ NCT01349842, accessed on 13.1. 2015. 
[60] NCT01619111. DETECT III - A Multicenter, Phase III Study to Compare Standard Therapy +/- Lapatinib in HER2-ve MBC-Patients With HER2+ve CTC [Internet]. 2012 Available from: https: //clinicaltrials.gov/ct2/show/NCT01619111, accessed on 13.1. 2015.

[61] NCT02035813. DETECT IV - A Study in Patients With HER2-negative Metastatic Breast Cancer and Persisting HER2-negative Circulating Tumor Cells (CTCs). [Internet]. 2014 Available from: https: //clinicaltrials.gov/ct2/show/ NCT02035813, accessed on 14.1. 2015.

[62] NCT01548677. Efficacy Study of Herceptin to Treat HER2negative CTC Breast Cancer (TREAT-CTC) [Internet]. 2012 Available from: https: //clinicaltrials.gov/ct2/show/ NCT01548677, accessed on 14.1. 2015.

[63] HAYASHI N, NAKAMURA S, TOKUDA Y, SHIMODA Y, YAGATA $\mathrm{H}$, et al. Prognostic value of HER2-positive circulating tumor cells in patients with metastatic breast cancer. Int J Clin Oncol 2012; 17: 96-104. http://dx.doi.org/10.1007/ s10147-011-0260-0

[64] LIGTHART ST, BIDARD FC, DECRAENE C, BACHELOT T, DELALOGE S, et al. Unbiased quantitative assessment of Her-2 expression of circulating tumor cells in patients with metastatic and non-metastatic breast cancer. Ann Oncol 2013; 24: 1231-1238. http://dx.doi.org/10.1093/annonc/ mds625

[65] PEREZ EA, ROMOND EH, SUMAN VJ, JEONG JH, DAVIDSON NE, et al. Four-year follow-up of trastuzumab plus adjuvant chemotherapy for operable human epidermal growth factor receptor 2-positive breast cancer: joint analysis of data from NCCTG N9831 and NSABP B-31. J Clin Oncol 2011; 29: 3366-3373. http://dx.doi.org/10.1200/ LCO.2011.35.0868

[66] ITHIMAKIN S, DAY KC, MALIK F, ZEN Q, DAWSEY SJ, et al. HER2 drives luminal breast cancer stem cells in the absence of HER2 amplification: implications for efficacy of adjuvant trastuzumab. Cancer Res 2013; 73: 1635-1646. http://dx.doi. org/10.1158/0008-5472.CAN-12-3349

[67] GEORGOULIAS V, BOZIONELOU V, AGELAKI S, PERRAKI M, APOSTOLAKI S, et al. Trastuzumab decreases the incidence of clinical relapses in patients with early breast cancer presenting chemotherapy-resistant CK-19mRNApositive circulating tumor cells: results of a randomized phase II study. Ann Oncol 2012; 23: 1744-1750. http://dx.doi. org/10.1093/annonc/mds020

[68] HEITZER E, AUER M, GASCH C, PICHLER M, ULZ P, et al. Complex tumor genomes inferred from single circulating tumor cells by array-CGH and next-generation sequencing. Cancer Res 2013; 73: 2965-2975. http://dx.doi. org/10.1158/0008-5472.CAN-12-4140

[69] LOHR JG, ADALSTEINSSON VA, CIBULSKIS K, CHOUDHURY AD, ROSENBERG M, et al. Whole-exome sequencing of circulating tumor cells provides a window into metastatic prostate cancer. Nat Biotechnol 2014; 32: 479-484. http:// dx.doi.org/10.1038/nbt.2892

[70] YU M, BARDIA A, ACETO N, BERSANI F, MADDEN MW, et al. Cancer therapy. Ex vivo culture of circulating breast tumor cells for individualized testing of drug susceptibil- ity. Science 2014; 345: 216-220. http://dx.doi.org/10.1126/ science. 1253533

[71] AMIR E, MILLER N, GEDDIE W, FREEDMAN O, KASSAM F, et al. Prospective study evaluating the impact of tissue confirmation of metastatic disease in patients with breast cancer. J Clin Oncol 2012; 30: 587-592. http://dx.doi.org/10.1200/ LCO.2010.33.5232

[72] THOMPSON AM, JORDAN LB, QUINLAN P, ANDERSON E, SKENE A, et al. Prospective comparison of switches in biomarker status between primary and recurrent breast cancer: the Breast Recurrence In Tissues Study (BRITS). Breast Cancer Res 2010; 12: R92. http://dx.doi.org/10.1186/ $\underline{\text { bcr } 2771}$

[73] RIETHDORF S, MULLER V, ZHANG L, RAU T, LOIBL S, et al. Detection and HER2 expression of circulating tumor cells: prospective monitoring in breast cancer patients treated in the neoadjuvant GeparQuattro trial. Clin Cancer Res 2010; 16: 2634-2645. http://dx.doi.org/10.1158/1078-0432.CCR-09$\underline{2042}$

[74] MUNZONE E, NOLE F, GOLDHIRSCH A, BOTTERI E, ESPOSITO A, et al. Changes of HER2 status in circulating tumor cells compared with the primary tumor during treatment for advanced breast cancer. Clin Breast Cancer 2010; 10: 392-397. http://dx.doi.org/10.3816/CBC.2010.n.052

[75] MOURIDSEN H, GERSHANOVICH M, SUN Y, PEREZCARRION R, BONI C, et al. Phase III study of letrozole versus tamoxifen as first-line therapy of advanced breast cancer in postmenopausal women: analysis of survival and update of efficacy from the International Letrozole Breast Cancer Group. J Clin Oncol 2003; 21: 2101-2109. http://dx.doi.org/10.1200/ LCO.2003.04.194

[76] BONNETERRE J, THURLIMANN B, ROBERTSON JF, KRZAKOWSKI M, MAURIAC L, et al. Anastrozole versus tamoxifen as first-line therapy for advanced breast cancer in 668 postmenopausal women: results of the Tamoxifen or Arimidex Randomized Group Efficacy and Tolerability study. J Clin Oncol 2000; 18: 3748-3757.

[77] NADAL R, FERNANDEZ A, SANCHEZ-ROVIRA P, SALIDO M, RODRIGUEZ M, et al. Biomarkers characterization of circulating tumour cells in breast cancer patients. Breast Cancer Res 2012; 14: R71. http://dx.doi.org/10.1186/ bcr3180

[78] BABAYAN A, HANNEMANN J, SPOTTER J, MULLER V, PANTEL K, et al. Heterogeneity of estrogen receptor expression in circulating tumor cells from metastatic breast cancer patients. PLoS One 2013; 8: e75038. http://dx.doi.org/10.1371/ journal.pone.0075038

[79] AKTAS B, MULLER V, TEWES M, ZEITZ J, KASIMIR-BAUER S, et al. Comparison of estrogen and progesterone receptor status of circulating tumor cells and the primary tumor in metastatic breast cancer patients. Gynecol Oncol 2011; 122: 356-360. http://dx.doi.org/10.1016/j.ygyno.2011.04.039

[80] SOMLO G, LAU SK, FRANKEL P, HSIEH HB, LIU X, et al. Multiple biomarker expression on circulating tumor cells in comparison to tumor tissues from primary and metastatic sites in patients with locally advanced/inflammatory, and stage IV breast cancer, using a novel detection technology. 
Breast Cancer Res Treat 2011; 128: 155-163. http://dx.doi. org/10.1007/s10549-011-1508-0

[81] LOIBL S, VON MINCKWITZ G, SCHNEEWEISS A, PAEPKE S, LEHMANN A, et al. PIK3CA mutations are associated with lower rates of pathologic complete response to anti-human epidermal growth factor receptor 2 (her2) therapy in primary HER2-overexpressing breast cancer. J Clin Oncol 2014; 32: 3212-3220. http://dx.doi.org/10.1200/ JCO.2014.55.7876

[82] HIGGINS MJ, JELOVAC D, BARNATHAN E, BLAIR B, SLATER S, et al. Detection of tumor PIK3CA status in metastatic breast cancer using peripheral blood. Clin Cancer Res 2012; 18: 3462-3469. http://dx.doi.org/10.1158/1078-0432. CCR-11-2696

[83] MARKOU A, FARKONA S, SCHIZA C, EFSTATHIOU T, KOUNELIS S, et al. PIK3CA mutational status in circulating tumor cells can change during disease recurrence or progression in patients with breast cancer. Clin Cancer Res 2014; 20 : 5823-5834. http://dx.doi.org/10.1158/1078-0432.CCR-14$\underline{0149}$

[84] DENG G, KRISHNAKUMAR S, POWELL AA, ZHANG $\mathrm{H}, \mathrm{MINDRINOS} \mathrm{MN}$, et al. Single cell mutational analysis of PIK3CA in circulating tumor cells and metastases in breast cancer reveals heterogeneity, discordance, and mutation persistence in cultured disseminated tumor cells from bone marrow. BMC Cancer 2014; 14: 456. http://dx.doi. org/10.1186/1471-2407-14-456

[85] KALLERGI G, AGELAKI S, KALYKAKI A, STOURNARAS C, MAVROUDIS D, et al. Phosphorylated EGFR and PI3K/ Akt signaling kinases are expressed in circulating tumor cells of breast cancer patients. Breast Cancer Res 2008; 10: R80. http://dx.doi.org/10.1186/bcr2149

[86] NOOTER K, BRUTEL DE LA RIVIERE G, LOOK MP, VAN WINGERDEN KE, HENZEN-LOGMANS SC, et al. The prognostic significance of expression of the multidrug resistance-associated protein (MRP) in primary breast cancer.
Br J Cancer 1997; 76: 486-493. http://dx.doi.org/10.1038/ bjc. 1997.414

[87] SACHDEV D, YEE D. The IGF system and breast cancer. Endocr Relat Cancer 2001; 8: 197-209. http://dx.doi.org/10.1677/ erc. 0.0080197

[88] CIERNA Z, MEGO M, JANEGA P, KARABA M, MINARIK $\mathrm{G}$, et al. Matrix metalloproteinase 1 and circulating tumor cells in early breast cancer. BMC Cancer 2014; 14: 472. http:// dx.doi.org/10.1186/1471-2407-14-472

[89] SINGH JK, FARNIE G, BUNDRED NJ, SIMOES BM, SHERGILL A, et al. Targeting CXCR1/2 significantly reduces breast cancer stem cell activity and increases the efficacy of inhibiting HER2 via HER2-dependent and -independent mechanisms. Clin Cancer Res 2013; 19: 643-656. http:// dx.doi.org/10.1158/1078-0432.CCR-12-1063

[90] PLANTAMURA I, CASALINI P, DUGNANI E, SASSO M, D'IPPOLITO E, et al. PDGFRbeta and FGFR2 mediate endothelial cell differentiation capability of triple negative breast carcinoma cells. Mol Oncol 2014; 8: 968-981. http://dx.doi. org/10.1016/j.molonc.2014.03.015

[91] WENDT MK, TAYLOR MA, SCHIEMANN BJ, SOSSEYALAOUI K, SCHIEMANN WP. Fibroblast growth factor receptor splice variants are stable markers of oncogenic transforming growth factor betal signaling in metastatic breast cancers. Breast Cancer Res 2014; 16: R24. http://dx.doi. org/10.1186/bcr3623

[92] JIWA LS, VAN DIEST PJ, HOEFNAGEL LD, WESSELING J, WESSELING P, et al. Upregulation of Claudin-4, CAIX and GLUT-1 in distant breast cancer metastases. BMC Cancer 2014; 14: 864. http://dx.doi.org/10.1186/1471-2407 -14-864

[93] D'ASSORO AB, LIU T, QUATRARO C, AMATO A, OPYRCHAL $\mathrm{M}$, et al. The mitotic kinase Aurora--a promotes distant metastases by inducing epithelial-to-mesenchymal transition in ERalpha(+) breast cancer cells. Oncogene 2014; 33: 599-610. http://dx.doi.org/10.1038/onc.2012.628 